\title{
«Du overprøver ikke en lege»
}

\author{
Nylig hadde jeg et lite hyggelig møte med helsevesenet. Jeg hadde \\ hanglet i 14 dager med feber, det var langhelg og jeg var lei av å gå syk.
}

Jeg ringte legevakten for å spørre om jeg kunne få tatt en CRP. Jeg ble litt overrasket da jeg fikk en hyggelig tilbakemelding om at jeg bare måtte komme. Dersom prøven ga utslag, skulle jeg også få snakke med lege.

Testen viste litt forhøyede verdier, og legen som tok imot meg, syntes han hørte en bilyd på hjertet. Han ringte sykehuset for å diskutere saken. Legene ble raskt enig om at jeg burde legges inn til nærmere utredning. Noe omtåket gikk jeg fra legevakten til mottakelsen, rett borti gangen. Selv hadde jeg regnet med at jeg kanskje ble sendt hjem med en antibiotikakur, tanken på et sykehusopphold hadde ikke falt meg inn.

\section{På sykehuset}

I mottakelsen ble jeg plassert $i$ et undersøkelsesrom, ble bedt om å ikle meg sykehusets pasientuniform og legge meg i sengen. Jeg ble godt og omsorgsfullt ivaretatt av en sykepleier. Et visst antall glass med blod ble tappet, så fikk jeg beskjed om at legen ville komme. Jeg fikk ringt hjem og gitt beskjed om at jeg var lagt inn. Jeg prøvde å lese litt i en bok jeg hadde tatt med som tidsfordriv for tiden jeg trodde jeg skulle tilbringe på legevakten.

Ut på ettermiddagen dukket turnuslegen opp. Da lå jeg og leste i boken. Jeg la den fra meg på sengen, så opp på legen og ble ikke lite overrasket over spørsmålet jeg fikk. Han spurte, litt «bøst» slik jeg opplevde det: «Hvorfor ligger du her?» Jeg ble litt overrumplet, men før jeg rakk å svare tok han boken og begynte å bla i den. For meg virket han lite interessert $i$ hva jeg hadde å fortelle. Jeg fikk summet meg og svarte at det hadde jeg egentlig tenkt at han skulle fortelle meg, fordi jeg selv var overrasket over at jeg var blitt innlagt. Etter å ha bladd i boken og kikket på forsidebildet, gikk han til datamaskinen for å se hva som sto om meg der. Et lite apropos: Hvorfor er slike datamaskiner plassert slik at legen blir sittende med ryggen til pasienten? Mens han leste, begynte han samtidig å stille en rekke spørsmål med mange medisinske faguttrykk som jeg ikke forsto. Jeg måtte derfor avbryte og spørre hva han mente. Han spurte om han skulle snakke doktorspråk eller vanlig til meg. Jeg svarte at han helst måtte snakke vanlig til meg, men gjerne doktorspråk til min kone. Hun er sykepleier og var kommet som min trøst og støtte.

Han lyttet på hjertet mitt, og ga uttrykk for at han var usikker på hva det var som feilte meg, hvilket jeg hadde stor forståelse for. Plutselig forsvant han ut. Mens han var ute, snakket min kone og jeg om at jeg kanskje burde gi tilbakemelding på at det var forvirrende å bli møtt med et spørsmål om hvorfor jeg lå på sykehuset. Da han returnerte, dristet jeg meg derfor til å spørre om akkurat det og la til at jeg hadde blitt litt satt ut av spørsmålet. Slik jeg oppfattet det, tolket han dette som et uttrykk for at jeg var irritert, noe jeg mener jeg ikke var. Han fortalte da at dette var et åpningsspørsmål han alltid stilte.

Så begynte han å tenke høyt om hvilken mulig diagnose jeg kunne ha. Slik jeg opplevde det, svingte mulighetene fra at jeg var dødssyk, med betennelse i hjertet eller hjerteklaffene, og til at jeg kunne reise hjem umiddelbart som frisk. Når vi begynte å etterspørre den alvorligste diagnosen, startet han med å fortelle at han selv, for ikke lenge siden, hadde tatt imot en pasient med tilsvarende symptomer som meg og som plutselig hadde dødd av det. Ikke nok med at han fortalte historien, men han kastet seg over skrivebordet for å demonstrere hvordan det hadde foregått da pasienten trakk sitt siste sukk.

Jeg ble rystet over hva legen kunne få seg til å gjøre. Når han i tillegg demonstrerte dødsøyeblikket for meg, mistet jeg munn og mæle. Dette ga jeg også uttrykk for ved å si at dette var en historie jeg ikke trengte å høre akkurat nå. Mitt forsøk på å stoppe førte isteden til at historien ble fortalt en gang til. Da ble både jeg og min kone irritert og ba ham tie.

Legen konkluderte med at min irritasjon var en bekreftelse på at det var noe galt med hjertet, fordi hjertepasienter ofte kan være noe irritable. Dette syntes jeg både var rart og noe forhastet, så jeg stilte et åpent spørsmål tilbake om ikke den konklusjonen var trukket vel raskt. Legens svar var da følgende: «En pasient overprøver ikke en lege! Jeg innrømmer at samtalen nå var i ferd med å kjøre seg helt fast. Jeg ga opp. Min kone og jeg så på hverandre og ristet på hodet. Du har ikke studert medisin, det har jeg!»
Legeundersøkelsen endte med at det ble bestemt at jeg for sikkerhets skyld skulle legges inn til observasjon. Så fikk man avvente hva som ville skje.

\section{En ubehagelig opplevelse}

Hvorfor skriver jeg dette? Jeg innrømmer at jeg har brukt noe tid på å bearbeide denne, for meg, sjokkerende, ubehagelige og spesielle opplevelsen. Nå endte historien godt. Etter diverse undersøkelser ble både jeg og hjertet erklært friskt. Feberen forsvant og legen antok at jeg hadde hatt en øvre luftveisinfeksjon.

Jeg fulgte oppfordringen fra kolleger og klaget opplevelsen inn for kvalitetsutvalget ved sykehuset. Å klage var godt for meg. Særlig når jeg etter få dager fikk brev fra sykehuset hvor klinikksjefen på sykehusets vegne beklaget og takket for at jeg hadde meldt fra om erfaringen min. Det var en oppreisning.

Mitt møte med denne legen gjorde meg forvirret, usikker og frustrert. Tillit er helt avgjørende for både lege og pasient. I dette tilfellet ble tilliten undergravet.

\section{Terje Hærås}

terjeheras@gmail.com

Hans Bulows gate 5

3746 Skien 